\title{
Conscientious Exemptions: From Toleration to Neutrality; From Neutrality to Respect
}

\author{
John Adenitire*
}

\section{Introduction}

A judge of the Tax Chamber of the First Tier Tribunal is tasked with considering two claims for exemption from the legal duty on businesses to file their tax returns online. A paraphrasing of the relevant exemption provision says that

a person who the HMRC is satisfied is a practising member of a religious society or order whose beliefs are incompatible with the use of electronic communications is not required to make a return by an electronic return system. ${ }^{1}$

The two claimants before the judge challenge HMRC's decision not to grant them the exemption. The first claimant, call him Mr Climate Change, says that he believes that using electronic communications is immoral because it leads to climate change. He says that

He believes that consumption of fossil fuels induces climate change by increasing $\mathrm{CO} 2$ in the atmosphere, and that internet usage puts more $\mathrm{CO} 2$ in the atmosphere than aviation. He objects to 'paperless' communications on the grounds that he considers paper communications create 'carbon sinks' to reduce $\mathrm{CO} 2$ in the atmosphere whereas electronic data centres burn massive amounts of carbon fuels thus increasing $\mathrm{CO} 2$ in the atmosphere. ${ }^{2}$

The second claimant, call him Mr Bible Believer, says that he should be granted the exemption because the Bible is against the use of electronic communications. He says that

The content of some television programmes and internet websites [are] contrary to the Bible's teaching as he [understands] it. But in addition, he [considers] computers and television as a whole as forms of "worldliness" which might seduce people away from "righteousness". (...) $\mathrm{He}$ [considers] that people [are] obsessed by them, almost regarding them as "idols". (...) He considers that modern media and in particular the "screen" has "blinded the minds of nonbelievers" and that people's time is so taken up with electronic communications that they no longer have time for religion in their lives. ${ }^{3}$

What moral considerations should guide the judge in reaching a decision on who should benefit from the exemption? Should he take more seriously the claim by Mr Bible Believer because of the implications for religious freedom inherent in his claim? But is concern for the environment not as equally compelling as concern for religious freedom? What moral principle best explains and should guide the practice of the judge considering to grant exemptions to these conscientious objectors?

\footnotetext{
* This paper was written while a Visiting Research Fellow at Yale Law School. Many thanks to Professor Patrick Weil for making my fellowship possible. Previous drafts were presented at research seminars in Cambridge and at the LARSN 2016 conference. Thanks are due to the various organisers and participants. Special thanks to Professor TRS Allan, Yossi Nehushtan, Joshua Neoh, Raffael Fasel and Ya Lan Chang for written comments. The paper is dedicated to Joseph Raz who generously discussed with me some of the ideas in the paper.

${ }^{1}$ Regulation 25A(6) of the Value Added Tax Regulations 1995.

2 Exmoor Coast Boat Cruises Ltd v Revenue \& Customs [2014] UKFTT 1103 [27].

${ }^{3}$ Blackburn \& Anor v Revenue \& Customs [2013] UKFTT 525 [13].
} 
The questions raised in the last paragraph apply to scenarios that go well beyond exemptions from online tax returns. Liberal states are faced with a wide variety of individuals demanding to be exempt from legal obligations that go to the very heart of liberalism. Some individuals have objected to celebrating same-sex marriages ${ }^{4}$; others to providing commercial services to homosexual couples ${ }^{5}$; some do not want to be involved in anything remotely associated with abortion or contraception ${ }^{6}$; some do not want to wear protective headgear while working or riding a motorcycle. ${ }^{7}$ The list could go on. The point being made here is that understanding what principles describe and should guide instances of requests for conscientious exemptions is an important one which may provide solutions to a recurring problem in liberal states.

Various distinguished scholars have risen to the challenge to solve this problem. They propose that the moral principle which best explains and should guide the practice of conscientious exemptions is that of toleration. ${ }^{8}$ The most recent and most vocal advocate of this view is Yossi Nehushtan, who will be the main interlocutor of this paper. In a paper published in this journal which he amplifies in his recent book, he argues that

[G]ranting conscientious exemptions is usually the outcome of tolerance and (...) the principle of tolerance better explains both the practice of granting conscientious exemptions and the attitude of those who grant exemption. ${ }^{9}$

Nehushtan is joined by other scholars in this view, including Brian Leiter and Peter Jones. ${ }^{10}$ From the principle of toleration Nehushtan is able to draw normative conclusions as to how and when conscientious exemptions should be granted. For example, following Nehushtan's complex views (to be explained below), the link between toleration and exemptions would result in Mr Bible Believer being more likely to lose his claim than Mr Climate Change.

The main purpose of this paper is to suggest that this view is misguided. The practice of conscientious exemptions is not best explained nor should it be mainly guided by the principle of toleration. It is not denied that toleration may at times help explain some of the features of this practice. However, it is argued that if toleration has at all any role to play in explaining or guiding the practice of conscientious exemption, that role should be kept within rigorous boundaries. Rather than making reference to toleration as an explanatory or guiding principle, ultimately it is best to make reference instead to a cluster of moral principles which better explain and provide solid normative foundations for the practice.

\footnotetext{
${ }^{4}$ Miller v Davis (No 15A250) (Supreme Court).

${ }^{5}$ Bull v Hall [2013] 1 WLR 3741.

${ }^{6}$ Burwell v Hobby Lobby Stores, Inc (2014) 134 SCt 2751 (Supreme Court); Doogan and another v Greater Glasgow and Clyde Health Board [2015] AC 640.

${ }^{7}$ VG Freiburg, Urt v 29102015 - 6 K 2929/14. This German case involved a Sikh unsuccessfully challenging the obligation to wear a helmet while riding a motorbike.

${ }^{8}$ In line with much scholarship, this paper uses tolerance and toleration as synonymous. This is however not a semantic issue without its problems. See Andrew R Murphy, 'Tolerance, Toleration, and the Liberal Tradition' (1997) 29 Polity 593.

${ }^{9}$ Yossi Nehushtan, Intolerant Religion in a Tolerant-Liberal Democracy (Hart Publishing 2015) 129-130; Yossi Nehushtan, 'What Are Conscientious Exemptions Really About?' (2013) 2 Oxford Journal of Law and Religion 395-397.

${ }^{10}$ Brian Leiter, 'Reply to Five Critics of Why Tolerate Religion?' [2016] Criminal Law and Philosophy 1, 6. He here replies to François Boucher and Cécile Laborde, 'Why Tolerate Conscience?' [2014] Criminal Law and Philosophy 1. For a more general defence of the relationship between toleration and conscientious exemptions see Brian Leiter, Why Tolerate Religion? (Princeton University Press 2013) 68-134. Peter Jones, 'Accommodating Religion and Shifting Burdens' [2014] Criminal Law and Philosophy 1, 2. A full argument is provided in Peter Jones, 'Toleration, Religion and Accommodation' (2015) 23 European Journal of Philosophy $542,550-551$.
} 
As to be developed in detail below, the main reason for marginalising toleration is that in judicial practice regarding conscientious exemptions the law has committed itself to the principle of neutrality towards the content of conscientious objectors' beliefs. Doctrinal and normative evidence will be adduced to show that the law on conscientious exemptions rightly marginalises toleration as the basis of conscientious exemptions. If this argument is right and toleration is and ought to be marginalised by the law of conscientious exemptions, then toleration cannot help us determine when and how exemptions should be granted. Instead, we would have to make recourse to a cluster of moral principles which explain and guide that practice. That cluster is complex and contains various principles, including respect for state neutrality, autonomy, conscience and well-being. It is by being attentive to this cluster of principles and paying due respect to them that liberal states may begin to acquire principled answers to the problems raised by conscientious exemptions.

Part 2 of this essay explains why Nehushtan and others make recourse to toleration to explain the practice of conscientious exemptions. It also explains the practical significance of the link between toleration and exemptions. Part 3 explains why the principle of toleration cannot and should not do the work Nehushtan and others want it to do. Doctrinal and normative arguments are adduced to show that the law of various liberal states prohibit judges considering exemptions from passing moral judgement on the content of the beliefs of conscientious objectors. In short, the law rightly embraces neutrality and marginalises toleration. Part 4 provides an alternative to toleration as the basis of conscientious exemptions. It argues that it is respect for a cluster of moral principles which should guide the practice of conscientious exemptions. Under that view, Mr Climate Change and Mr Bible Believer have similar chances of winning their claims.

\section{Conscientious Exemptions, Toleration and Why the Link Between the Two Matters}

This part explains what Nehushtan takes the concept of toleration to be. It then shows why Nehushtan thinks that toleration best explains and should guide the practice of conscientious exemptions. Finally, it explains the significance of this view for the way liberal states should deal with specific instances of conscientious exemptions.

\section{A. What is Toleration?}

According to Nehushtan, 'People make adverse judgments about others. These judgments may provide reasons to harm or offend the others. Yet the tolerant person has reasons--any type of reasons--not to act in certain ways that may harm or offend another'. ${ }^{11}$ Similarly, Brian Leiter argues that toleration is an act "of "putting up" with practices of which one disapproves because it is morally right to do so'. ${ }^{12}$ Peter Jones is perhaps the more nuanced of the three. He provides a similar definition of toleration but admits that applying this definition in the context of conscientious exemptions raises complications. Those complications will be analysed in due course. For now, it suffices to say that Jones provides a very similar initial definition of toleration to Nehushtan and Leiter. He says that

In simple analyses of toleration, we frequently use a model of person-to-person toleration. Person A objects to the conduct of person B, is able to prevent B's conduct if he so chooses, but allows $B$ to continue with that conduct. In that case, A tolerates B's conduct. ${ }^{13}$

At the basis of these similar definitions of toleration is the precondition of an adverse moral judgement towards the person being tolerated. All three scholars agree that one of the essential ingredients is

\footnotetext{
${ }^{11}$ Nehushtan, 'What Are Conscientious Exemptions Really About?' (n 9) 395.

12 Leiter, Why Tolerate Religion? (n 10) 3.

13 Jones, 'Toleration, Religion and Accommodation' (n 10) 545.
} 
that the tolerant person must, in order to be considered tolerant, hold a negative moral judgement about the person that is being tolerated. As Leiter puts it, "toleration is not at issue in cases where one group is simply indifferent to another. ${ }^{14}$ One can also add that toleration is not at issue when one person or group has a positive moral judgement about another person or group. A second essential ingredient is that the negative moral judgement gives the tolerant person reasons to occasion harm to the tolerated. Finally, and importantly, the last ingredient is that the tolerant person accepts that there are reasons which are sufficient to refrain from harming the tolerated despite the existence of the negative moral judgement.

\section{B. Are Conscientious Exemptions Instances of Toleration?}

A brief sketch of the concept of toleration was provided in the previous part. This part explains why Nehushtan regards conscientious exemptions as instances of toleration. He has argued in this journal that

typically, granting conscientious exemptions from a legal rule presupposes that the state does not share the conscientious objector's values (...). Otherwise, the exemption would have been the general rule rather than the exemption to it. In other words, the state usually makes an adverse judgment about the conscientious objector's values (...). This judgment gives the state reasons not to grant the conscientious objector an exemption from the legal rule (thereby harming him). If the state decides to grant conscientious exemptions after all, it can be seen as tolerant. ${ }^{15}$

Nehushtan's argument seems plausible and fairly intuitive. It may be applied to the tax exemption scenario considered above. In that scenario the state does not consider that filing tax returns online is morally problematic and therefore imposes the general rule that tax returns should be filed electronically. By imposing this general rule the state may be viewed as not sharing the values of $\mathrm{Mr}$ Bible Believer or Mr Climate Change. If the state had held these values, it would have imposed a general rule that tax returns should be filed on paper and not electronically. The state may therefore be viewed as holding an adverse moral judgement about the unusual views of Mr Bible Believer or $\mathrm{Mr}$ Climate Change. This adverse moral judgement gives the state reason to employ its coercive arm to force the claimants to comply with the general rule. However, for a variety of reasons which we shall not investigate, the state has refrained from coercing the claimants and has provided an exemption which Mr Bible Believer and Mr Climate Change may in principle benefit from. The availability of this exemption appears then to be an instance of toleration.

It is worth noting at this point that Nehushtan employs Jones's person-to-person model of toleration which was described earlier. The person doing the toleration here is a personification of the state and the persons being tolerated here are Mr Bible Believer and Mr Climate Change. ${ }^{16}$

However, because the state is a complex aggregate of individuals and institutions, it is very problematic to attribute any one single intention or attitude to it without speaking metaphorically or by extension. Only real people and some animals hold actual intentions and attitudes and the state is not a real person. This is not to deny that institutions and state officials may speak on behalf of the state. However, it is very plausible that the various institutions and officials who represent the state may hold different and incompatible attitudes. It is for this reason that Jones is less inclined to identify the state as the person doing the toleration. He says that

the problem of identifying a tolerator arises from use of the person-to-person model of toleration. Rather than viewing exemptions according to that model, we would do better to see

\footnotetext{
${ }^{14}$ Leiter, Why Tolerate Religion? (n 10) 8.

${ }^{15}$ Nehushtan, 'What Are Conscientious Exemptions Really About?' (n 9) 3.

${ }^{16}$ Leiter also adopts this personification. See Leiter, 'Reply to Five Critics of Why Tolerate Religion?' (n 10) 6.
} 
them as representing a society's public stance on what should and should not be tolerated.

Toleration is a feature of the exemptions themselves rather than an expression of any particular person's or party's toleration. ${ }^{17}$

Jones's strategy is ingenuous. Perceiving the personification problem associated with the person-toperson model he would abandon that model in the context of exemptions and simply state that exemptions represent a society's public stance on things that ought to be tolerated. But this is not less problematic than the person-to-person model. While it is not uncommon to speak of certain laws as representing society's commitment to one cause or another, a little analysis usually reveals that this manner of speech is either figurative or refers to specific individuals or a group of them. Just like the state, society is a complex aggregate of individuals and institutions the very components of which might hold different views about the desirability of the laws which allegedly represent their commitments (think, for example, of the very controversial laws allowing abortion or same-sex marriage). So it is best to speak of these laws, including exemptions, as either representing the views of those components of society which support them or, alternatively, as representing the views of the law-making institutions responsible for those laws. ${ }^{18}$ Of course, subject to the availability of exemptions, law enforcing institutions will be legally authorised to enforce hotly controversial laws irrespective of whether or not legal subjects accept that those laws represent their stance on particular issues.

\section{Why does it Matter that Conscientious Exemptions are Instances of Toleration?}

Let us, for now, put to one side the worries about the adequacy of fit between toleration and exemptions. Part 3 of this paper will be devoted entirely to unravelling those worries. Instead, let us consider what Nehushtan is trying to achieve by arguing that exemptions should be seen as instances of toleration. Nehushtan puts it very squarely when he says that

If, as I suggest, granting conscientious exemptions is in most cases the outcome of tolerance, then the practice of granting conscientious exemptions is closely related to the complex question of the limits of tolerance. Within this context we ask whether religion is special: whether there is something special about religion that justifies a greater or lesser amount of tolerance towards claims $(\ldots)$ to be granted conscientious exemptions. ${ }^{19}$

As the quote above indicates, Nehushtan's argument aims to show that the link between toleration and exemptions can help liberal states decide when conscientious exemptions should be granted. In his view, if there are limits to what ought to be tolerated then it may be that those limits indicate when certain exemptions should or should not be granted. In particular, his hypothesis is that there might be something special about religion that militates against toleration of religious beliefs and, therefore, militates against granting exemptions to religious objectors.

The title of Nehushtan's monograph (Intolerant Religion in a Tolerant-Liberal Democracy) gives away what he thinks is distinctive about religion: it is inherently intolerant. He argues at length that 'there are meaningful, unique links between religion and intolerance, and between holding religious beliefs and holding intolerant views (and ultimately acting upon these views)'. ${ }^{20}$ Embracing the liberal perfectionism of Raz, he argues that the principle of toleration requires that a liberal state should

\footnotetext{
17 Jones, 'Toleration, Religion and Accommodation' (n 10) 551.

${ }^{18}$ This argument was borrowed from John Gardner who is sceptical of similar personifications of, or attribution of attitudes to, the law. See John Gardner, 'How Law Claims, What Law Claims', Law as a Leap of Faith (Oxford University Press 2012) 126-127.

${ }^{19}$ Nehushtan, Intolerant Religion (n 9) 137.

20 ibid 3.
} 
discourage intolerant views ${ }^{21}$ (broadly speaking views which undermine the liberal commitment to civil and political rights). His conclusion is then that, given that religion is inherently intolerant, liberal democracies should discourage religious practices. This entails that whenever a claim for exemption is made by a religious conscientious objector, 'the religiosity of a legal claim is normally a reason, although not necessarily a prevailing one, to reject that claim'. ${ }^{22}$ This would entail that, all things being equal, in the context of the tax exemption above Mr Bible Believer should have a lesser chance of winning his claim than Mr Climate Change.

Many will be hesitant to agree with Nehushtan's views about the inherently intolerant nature of religion. Some have argued against the view that religion should be discouraged in a liberal democracy because there is no evidence that religious beliefs are inherently intolerant, although they sometimes are, or that they necessarily lead to intolerant practices, although they sometimes do. ${ }^{23}$ Others argue that religion is a distinctively worthwhile institution which should be highly valued in a liberal democracy. In fact they argue that exemptions should be more readily granted to religious conscientious objectors than to non-religious objectors given that religion should be particularly cherished and protected in a liberal state. An argument often adduced for this view is that religious commands, coming from a divine authority which is superior to human authority (including secular moral conscience), demand priority over non-religious commands, including secular laws. On this view, religious conscientious objectors deserve to be tolerated more than non-religious conscientious objectors. ${ }^{24}$ If this view is followed, Mr Bible Believer should have a higher chance of winning his claim than Mr Climate Change.

No issue will be taken here on whether or not religious belief is praiseworthy or deserves condemnation in the practice of conscientious exemptions. A stance need only be taken if the principle of toleration is used to ground that practice. Depending on the view taken on the merits of religious beliefs, if the principle of toleration guides the practice, then religious objectors will be better or worse off than non-religious objectors. The position to be defended here is that the question as to the merits of religious beliefs is mute as the principle of toleration has at most a marginal role in describing, and should have little role in guiding, the practice of conscientious exemptions. It is to this defence that part 3 is devoted.

\section{Conscientious Exemptions: From Toleration to Neutrality}

This section explores why the practice of granting conscientious exemptions is never straightforwardly an instance of toleration. First, when we investigate the attitude of the individuals responsible for granting a statutory exemption the result is often inconclusive: some members of the legislature may display the attitude of toleration while others will not. This is an empirical matter which will often be variable depending on the exemption at play. More fundamentally, however, the attitudes of the members of the legislature cannot be attributed to the legislature as an institution. What the legislature intended and what attitude should be attributed to it when it grants a particular statutory exemption is a matter to be authoritatively determined by the judiciary. However, it is clear that the jurisprudence of various liberal states prohibits judges from pronouncing any moral judgement, especially of a negative character, regarding the content of the beliefs of conscientious objectors. In doing so, the law commands neutrality towards the beliefs of the objector and thereby prevents

\footnotetext{
${ }^{21}$ He makes his main argument in ibid Chapter 3.

22 ibid 3.

23 Some arguments are adduced in this respect in John Adenitire, 'The Irrelevance of Religion' 2017 (forthcoming) Jurisprudence.

${ }^{24}$ Kathleen A Brady, The Distinctiveness of Religion in American Law: Rethinking Religion Clause Jurisprudence (Cambridge University Press 2015). Michael Stokes Paulsen, 'Is Religious Freedom Irrational' (2013) 112 Michigan Law Review 1043.
} 
judges from holding the attitude of toleration when they grant an exemption. Toleration therefore has at best a very minor role to play when considering conscientious exemptions.

\section{A. Attitude of legislative officials granting exemptions}

On 1 October 2015 section 6 of the Deregulation Act came into effect. It amended section 11 of the Employment Act 1989. Its effect was to exempt Sikhs from the requirement to wear safety helmets during employment in any workplace, with the exception of when involved in hazardous activities in dangerous workplaces like the army and emergency services. When the Deregulation Bill was being debated in the House of Commons, the Solicitor-General, who sponsored the Bill on behalf of the UK Government, spent some time echoing the praises offered by various speakers towards the Sikh community. He said

Finally, I agree with what the hon. Member for Chesterfield said about the Sikhs. They are a fantastic group who have added so much to this country and their history is, as he outlined, a very important part of our cultural background as a country. The amendments will be widely welcomed in the Sikh community $(\ldots) .{ }^{25}$

There was no mention throughout his speech nor throughout that of many other speakers in the House of Commons (nor in the House of Lords for that matter) ${ }^{26}$ of any negative moral judgement towards the Sikh community or towards their beliefs, whether or not related to the wearing of headgear. Should we then assume that the UK Parliament when it passed the legislation granting the exemption was not acting in a tolerant fashion? If there was no negative judgement which was nevertheless followed by the grant of the exemption we should conclude that there was no attitude of toleration by the legislature. This would seem as a direct empirically-based counter-argument to Nehushtan's and other's view that exemptions are instances of toleration.

We should pause before reaching such a conclusion. First, at least one member of the legislature potentially acted in a tolerant fashion. In his speech in the House of Commons, Kevin Hopkins expressed his general condemnation of workers not wearing safety headgear at work. However, perhaps because a considerable number of his North Luton constituency are Sikhs, he decided to support the grant of the exemption. His tolerant attitude is evident from his own words:

I [have] argued strongly that wearing safety helmets on site should be compulsory and a matter for the law, because many site workers would not wear a hard hat unless required to do so. That was important, but, of course, I entirely understand and support the exception for Sikhs. Nevertheless, these days many Sikhs choose not to wear the turban-they pursue their faith in other ways. One assumes that Sikhs who do not wear the turban and who are working on sites will be covered by the same rules as all the other people on site-namely, they will be required to wear a hard hat. ${ }^{27}$

Perhaps we should conclude that the legislative grant of the exemption was after all an instance of toleration given Kevin Hopkins's views regarding the matter. That would appear however counterintuitive given that he was the only speaker that displayed an attitude of toleration. Should we reach the opposite conclusion and say that the exemption was not granted out of toleration but rather out of admiration for the Sikh community? This seems more likely as the majority of those that spoke in the Houses of Parliament appear to have held that view.

However, we should pause again before affirming this conclusion. Remember that the exemption is a result of the UK Parliament's action and intentions. Parliament is an institution and its actions, intent

\footnotetext{
${ }^{25}$ Deregulation Bill Debate 25 March 2015, col 584.

${ }^{26}$ HL Deb 21 October 2014 Vol 756, Col 587.

27 Deregulation Bill Debate 25 March 2015, col 582.
} 
and attitudes are different from that of its constituent members. It is now firmly ingrained in constitutional theory that legislative intent cannot be a simple matter of aggregating the collective intentions of the individual members of the legislature. ${ }^{28}$ As we have seen when discussing the views of the Solicitor-General and of Kevin Hopkins, the individual members may hold different or conflicting attitudes. Also, it is unhelpful to point to the mental state of those sponsoring the particular legislation (e.g. the Solicitor-General in this case): their vote on whether to grant the exemption do not count any more than those who did not sponsor the Bill. Even if the majority of the members voted with a certain view or attitude we cannot extend the majority's view to the entire institution of the legislature, except metaphorically. That would entail excluding the minority's views or attitudes from that of the legislature which would not be correct as they are part of the legislature.

None of the above should be taken to indicate that the legislature as an institution cannot form intentions or that legislation, including statutory exemptions, cannot be enacted for certain purposes. Rather, the implication of the above discussion is that the attitudes of the members of the legislature cannot be conclusive evidence that an exemption was granted because the legislature tolerated the conscientious objector. It is here suggested that if we want to ascertain legislative intention and statutory purpose in the context of statutory exemptions we would better look to the institution whose main job is to ascertain legislative intent and statutory purpose: the judiciary. However, as the next section suggests, judges considering conscientious exemptions are, for doctrinal reasons which reflect valid moral reasons, more than hesitant to express a negative moral judgement about the beliefs of conscientious objectors. If this is true, then judges cannot be engaging in the practice of toleration when engaged in the practice of considering whether to grant conscientious exemptions.

\section{B. Attitudes of judicial officials granting exemptions: the imperative of neutrality}

In the previous section, the paper concluded that toleration can at most sometimes explain the attitude of certain members of the legislature who vote in favour of a statutory exemption. This section shows that when judicial conscientious exemptions are considered, toleration has even a much narrower role to play. This is because various doctrines prohibit judges from expressing negative moral judgements about the content of the beliefs of conscientious objectors.

If the principle of toleration best explains the practice of conscientious exemptions, as Nehushtan would have us believe, then we would expect judges considering cases such as those of Mr Bible Believer and $\mathrm{Mr}$ Climate Change to spend a good portion of their judgments on whether belief in the Bible or the ethics of climate change is rational, desirable, correct etc. Not only that. If we were to follow Nehushtan's view we would expect such judgments to tell us why belief in the Bible or the ethics of climate change is irrational, undesirable, incorrect, etc. This is because the principle of toleration necessarily requires a negative moral judgement by the person being tolerant towards conscientious objectors.

However, analysis of the judicial doctrine on conscientious exemptions in various liberal states is very likely to disappoint those who follow Nehushtan's view. ${ }^{29}$ Not only do judges not normally engage in

\footnotetext{
${ }^{28}$ Otherwise diverse scholars such as Dworkin, Waldron, Ekins and Goldsworthy hold the same view. See Ronald M Dworkin, Law's Empire (Hart Publishing 1998) ch 9. Jeremy Waldron, Law and Disagreement (Oxford University Press 1999) ch 6. Richard Ekins, The Nature of Legislative Intent (Oxford University Press 2012) ch 8. Jeffrey Goldsworthy, Parliamentary Sovereignty: Contemporary Debates (Cambridge University Press 2010) ch 9.

${ }^{29}$ There is some recent and useful literature on this. See Anna Su, 'Judging Religious Sincerity' (2016) 5 Oxford Journal of Law and Religion 28 . Note that the claim is only made in relation to the practice of conscientious exemptions. There might be other areas of law, e.g. church property and succession cases, where judges are
} 
evaluating or condemning the moral beliefs of conscientious objectors; but prevailing doctrines prohibit them from doing so. It is here assumed that, albeit they may fall short of the ideal, the US, Canada and most states party to the European Convention of Human Rights (ECHR), including the UK, are typical examples of liberal democracies towards which Nehushtan's work is addressed. In all of these jurisdictions judicial doctrine consistently prohibits moral judgement of the correctness or desirability of the moral beliefs of conscientious objectors.

Let us start with the US. Take the recent and seminal case of Hobby Lobby ${ }^{30}$ where the US Supreme Court (USSC) exempted a for-profit corporation from the obligation to provide insurance cover which would enable Hobby Lobby's employees to have free access to contraception. That decision was reached under the Religious Freedom Restoration Act 1993 (RFRA) which prohibits government from substantially burdening a person's religious freedom except in pursuance of a compelling interest and through the least restrictive means available to pursue that interest. The USSC held that providing contraception cover would substantially burden the free exercise of religion of Hobby Lobby's owners who were Evangelical Christians that believed some of those contraceptives to be abortifacient. The Secretary of Health and Human Services (HHS) argued that 'providing the coverage would not itself result in the destruction of an embryo; that would occur only if an employee chose to take advantage of the coverage'. ${ }^{31}$ The USSC refused to be involved in having to assess the merits of the religious beliefs of Hobby Lobby's owners. It said that HHS's argument

addresses a very different question that the federal courts have no business addressing (whether the religious belief asserted in a RFRA case is reasonable) (...) [HHS's argument] in effect tell[s] the plaintiffs that their beliefs are flawed. For good reason, we have repeatedly refused to take such a step. ${ }^{32}$

The USSC then went on to list a series of authorities, including Thomas and Smith, ${ }^{33}$ which had affirmed that doctrine. The Court stated that 'repeatedly and in many different contexts, we have warned that courts must not presume to determine ... the plausibility of a religious claim'; 'our "narrow function ... in this context is to determine" whether the line drawn reflects "an honest conviction". ${ }^{34}$

Canada has followed a similar path. Take the case of Amselem where the Supreme Court of Canada (SCC) held that Jewish property owners could be exempt from bye-laws which prohibited them from building religious huts (succahs) on their property in a condominium. The condominium managers had offered to make available communal succahs as an alternative. They argued that the insistence of the Jewish property owners to build their private succahs on their own property was not a requirement of the official teachings of their religion. The SCC refused to be involved in having to assess the orthodoxy of the claimants' beliefs. The Court stated that

the State is in no position to be, nor should it become, the arbiter of religious dogma.

Accordingly, courts should avoid judicially interpreting and thus determining, either explicitly or implicitly, the content of a subjective understanding of religious requirement, "obligation", precept, "commandment", custom or ritual. Secular judicial determinations of theological or

more likely to investigate religious doctrine. See, in the UK, Shergill \& Others v Khaira \& Others [2014] UKSC 33. In the US, see Jones $v$ Wolf (1979) 443 US 595 (Supreme Court).

${ }^{30}$ Hobby Lobby (n 6).

31 ibid 35.

32 ibid 36.

${ }^{33}$ Thomas v Review Bd of Indiana Employment Security Div (1980) 450 US 707 (Supreme Court). Employment Division v Smith 485 US 660 (Supreme Court).

${ }^{34}$ Hobby Lobby (n 6) 37-38. 
religious disputes, or of contentious matters of religious doctrine, unjustifiably entangle the court in the affairs of religion. ${ }^{35}$

The SCC then went on to state that, similarly to the USSC, despite refusing to assess the content of the belief that gave rise to a conscientious objection, it had the power to assess the sincerity of the claimant. It said that 'while a court is not qualified to rule on the validity or veracity of any given religious practice or belief, or to choose among various interpretations of belief, it is qualified to inquire into the sincerity of a claimant's belief'. ${ }^{36}$

Similar reasoning was adopted in the European Court of Human Rights (ECtHR) in Eweida which has been consistently followed by UK courts. ${ }^{37}$ In that case, two out of the four claimants were subject to disciplinary proceedings by their employers for refusing to comply with their employers' uniform policy by visibly wearing a Christian crucifix at work. They had unsuccessfully sought to be exempt from the policy. The UK government argued that 'the visible wearing of a cross was [not] a generally recognised form of practising the Christian faith, still less one that was regarded as a mandatory requirement'. ${ }^{38}$ Therefore, the UK argued, no protection should be afforded by article 9 of the ECHR to the objection to the uniform policy raised by the two claimants. The ECtHR took the same stance taken by the USSC and the SCC. It said that 'the State's duty of neutrality and impartiality is incompatible with any power on the State's part to assess the legitimacy of religious beliefs or the ways in which those beliefs are expressed'. ${ }^{39}$ This did not mean that any assertion of religious belief would automatically be protected by article 9 . The ECtHR said that 'The right to freedom of thought, conscience and religion [protected by article 9] denotes views that attain a certain level of cogency, seriousness, cohesion and importance'. ${ }^{40}$ This however is a very light touch enquiry by the courts. Guidance provided by the UK House of Lords, which was considered and not rejected by the ECtHR in Eweida ${ }^{41}$ indicates that a generous approach towards religious beliefs should be taken in undertaken this enquiry. The House of Lords said that

The belief must relate to matters more than merely trivial. It must possess an adequate degree of seriousness and importance. (...) it must be a belief on a fundamental problem. With religious belief this requisite is readily satisfied. The belief must also be coherent in the sense of being intelligible and capable of being understood. (...) But, again, too much should not be demanded in this regard. Typically, religion involves belief in the supernatural. It is not always susceptible to lucid exposition or, still less, rational justification (...) Overall, these threshold requirements should not be set at a level which would deprive minority beliefs of the protection they are intended to have under the Convention. ${ }^{42}$

The review above seems to show then that legal doctrines have been adopted in the UK, the ECtHR, Canada and US which prohibit judges considering conscientious exemption cases from passing any negative moral judgement on the moral permissibility or metaphysical truths of various ethical views that have given rise to a claim for conscientious exemption. This does not mean that these liberal democracies allow conscientious exemptions without scrutinising their effects. There are indeed

\footnotetext{
${ }^{35}$ Amselem v Syndicat Northcrest 2004 SCC 47 [50].

36 ibid 51.

${ }^{37}$ Eweida v United Kingdom 2013 IRLR 231. See Bull v Hall (n 5). Eweida has also been considered and followed in the tax exemption cases referred to above. See Exmoor (n 2). See Blackburn (n 3).

${ }^{38}$ Eweida (n 37) [81].

39 ibid.

40 ibid 81.

41 ibid 45.

${ }^{42} R$ (on the application of Williamson) $v$ Secretary of State for Education and Employment [2005] 2 AC 246 [23]. Under the ECHR non-religious beliefs which relate to matters more than merely trivial also enjoy similar protection. See Bayatna v Armenia (2012) 54 EHRR 15 [110]. See also Exmoor (n 2) [75].
} 
many cases in which a conscientious exemption was not granted because that would result in disproportionate harm to the rights of others (e.g. in Bull $v$ Hal/ ${ }^{43}$ exempting Christian B\&B owners from equality duties would result in impermissible harm to same-sex couples) or to the public interest (e.g. in Lee ${ }^{44}$ exempting the Amish from paying social security taxes would undermine an efficient national system of taxation). The standard test is that under Article 18 of the International Covenant on Civil and Political Rights (ICCPR) which says that

Freedom to manifest one's religion or beliefs [including obtaining a conscientious exemption] may be subject only to such limitations as are prescribed by law and are necessary to protect public safety, order, health, or morals or the fundamental rights and freedoms of others.

The existence of these legal doctrines therefore shows that, at least in relation to judicial consideration of conscientious exemptions, the practice of granting conscientious exemptions is not best described as an act of toleration. This is because judges do not, and cannot, grant or refuse to grant an exemption on the basis of an adverse moral judgement on the religious or non-religious beliefs of the claimants. As it might be apparent from some of the analysis above, judicial involvement in the practice of conscientious exemptions is a major part of the general practice of conscientious exemptions. If Nehushtan's principle of toleration does not hold true for the judicial practice of conscientious exemptions then it cannot provide an adequate explanation of the general practice of granting conscientious exemptions and the attitude of those who grant exemptions.

Before concluding this section, it is worth noting that even though judges are prohibited by law from expressing any negative moral judgement on the beliefs of conscientious objectors and in fact refrain from doing so in their judgments, it may still be the case that certain judges in their private capacity hold the views of conscientious objectors in contempt but, given their role, refrain from acting on their private views and follow the doctrinal injunction. In this instance Nehushtan may well be right that these judges display a measure of toleration. Nevertheless, just like in the case of the members of the legislature, such attitude cannot be attributed to the court or to the judge acting in official capacity. Furthermore, the existence of such mental state would be a constant variable of each individual judge acting in personal capacity and that cannot help us understand the institutional judicial practice of conscientious exemptions.

\section{Conscientious exemptions: From toleration to neutrality}

The previous section explained that judicial doctrines in various liberal states prohibit judges from expressing a negative moral judgement about the content of conscientious objectors' beliefs. That is a doctrinal matter and, if true, should be sufficient to undermine Nehushtan's thesis that conscientious exemptions are a matter of toleration. However, legal doctrines are not invariable and may develop to be the opposite of what they once were. It is therefore necessary to provide a moral argument in favour of the view that, independently of what legal doctrine says and what institutions do, the state has no place in expressing negative (or positive) moral judgements about the content of conscientious objectors' beliefs, i.e. it has a duty of neutrality.

Note that the argument to be provided is one about the content of beliefs (i.e. their truth, reasonableness, etc.) and not about acts undertaken by conscientious objectors. The state regularly takes a moral stance about the acts carried out in pursuant to a moral or religious belief. We have seen that, in the US for example, under the RFRA no exemption will be granted if it would interfere with a compelling government interest which cannot be protected in a way that is less restrictive on the conscientious objector's religious practices. Under the Art 18 ICCPR and the ECHR, an exemption cannot be granted if that is necessary to protect public safety, order, health, or morals or the fundamental rights and freedoms of others. So the position here defended is that the state ought

\footnotetext{
${ }^{43}$ Bull v Hall (n 5).

${ }^{44}$ United States v Lee 455 US 252.
} 
to be neutral in regards to the content of beliefs but cannot, and should not, be neutral when it comes to assessing the impact of the actions of a conscientious objector on vital public interests or on the rights of others.

What then can justify the duty of state neutrality? There are indeed multiple moral arguments. ${ }^{45}$ For sake of succinctness, only two arguments will be analysed here. These are the arguments from pluralism and from futility. Admittedly, only a shallow analysis of each will be provided here. Despite the shallowness, however, it will be possible to conclude that, as a moral matter, the state should not base its decision on whether to grant an exemption by, among other things, judging the content of the conscientious objector's beliefs.

\section{Pluralism}

The argument from pluralism holds that there are various ways to live a good life and, by implication, that there are various legitimate conceptions of what the good life is. A person may legitimately devote his life to religious contemplation or to the study of the intricacies of astrophysics. He may choose a life centred around family values or refuse to commit to a romantic relationship so as to focus on his career as an investment banker. No doubt there will be drawbacks in any of these lifestyles. A life of religious contemplation as a monk, while benefitting from high spirituality, is incompatible with the joys of family life. Studying the intricacies of astrophysics, while contributing to knowledge, is unlikely to yield the excitements and pecuniary rewards of the life of an investment banker. However, the point is that various incompatible lifestyles each exhibit something worthwhile, even while exhibiting several drawbacks, and it is up to each individual to weight for himself what is more worthwhile for him. Importantly, given that it is the individual that will benefit or suffer the consequences of the lifestyle, the choice of which lifestyle to follow is his and not the state's.

Note that the argument from pluralism is not an argument about moral relativism or nihilism, respectively the view that there is no universal way to establish the moral worth of different lifestyles or that different lifestyles cannot be better or worse than each other because morality does not exist. Rather the main thrust of the argument is that different lifestyles are objectively valuable in different ways and that the individual is the best judge of what is most valuable for him. The state should stay away from dictating what lifestyle is more valuable. Note also that this argument does not lead to undermining the legitimacy of state regulation of the interaction between different lifestyles. While individuals are free to choose what lives to live, they cannot impose their choices on others (they too have the right to choose what life to live). The role of the state then, as guardian of the common good, is to ensure that different lifestyles are compatible. The state can therefore limit acts that would undermine the common good and that would infringe others' right to choose which lifestyle is for them.

The argument from pluralism, if accepted, leads to accepting state neutrality in the context of conscientious exemptions in the same way that is reflected in the judicial doctrine analysed. The state has no role in telling Mr Bible Believer or Mr Climate Change not to devote their lives to religious beliefs or to deep concern for the environment. Both lifestyles exhibit something worthwhile despite their drawbacks and it is up to the individual to choose what is more worthwhile for him. However, given that both Mr Bible Believer and Mr Climate Change live in a society and are tax payers, the state is entitled to ensure that their moral choices do not adversely affect the tax system which is vital for the various worthwhile ends to be pursued by the state. Hence, the state, while not allowed to judge their views, is allowed to judge whether their decision not to file their tax returns online is compatible with a well-functioning taxation system.

\section{Futility}

\footnotetext{
${ }^{45}$ Koppelman identifies six of them. Andrew Koppelman, Defending American Religious Neutrality (Harvard University Press 2013) 18.
} 
Let us now consider the argument from futility. This says that it is futile for the state to express a view on the merits of the content of the beliefs of the objector for two reasons. First, such moral judgement is unlikely to lead the objector to change his beliefs. Second, the moral judgement is totally unnecessary for the more important task of safeguarding the public interest or the rights of others which the acts of the objector may undermine.

The first futility argument is really about the difficulty of changing the convictions of objectors, especially religious objectors. Judges and other state officials engaging in criticism of religious beliefs in a rational fashion are unlikely to affect any meaningful change in the belief systems of the objector. This is because religious beliefs are often held as a matter of faith. As Macklem argues

[F]aith exists as a form of rival to reason. When we say that we believe in something as a matter of faith, or to put it the other way round, when we say that we have faith in certain beliefs, we express a commitment to that which cannot be established by reason, or to that which can be established by reason, but not for that reason (...) faith treats itself as a reason to believe, and to act in accordance with belief, without submitting to the conditions of reason. ${ }^{46}$

When it comes to religious beliefs which state officials think are wrong, it is futile to engage the objector in conversations about how his beliefs are misguided unless the state official is able to speak the same faith-based language of the objector.

Even if the belief is non-faith based and is instead reason-based, such as that of Mr Climate Change, it might be equally futile to engage the objector in conversations about the merits of his beliefs. This is mainly because, in the context of a liberal democracy with free speech, the objector is likely to have already been exposed to all sorts of arguments that contradict his beliefs (e.g. that factory farming of animals is a more serious concern for climate change). Why would a state official expressing a contrary view to his make any difference? If the objector has gone through the trouble of litigation to secure an exemption in order to accommodate his beliefs that alone should give an indication of how deeply held and immoveable those beliefs are. This is not to say that deeply held beliefs are not changeable. However, we may be sceptical that the lengthy process that is necessary to revise one's deeply held beliefs can be successfully affected by state disapproval.

Even if the above were wrong, the second limb of the futility argument might still be convincing. It says that the more urgent task for state officials is to determine whether granting an exemption will undermine vital public interests or the rights of others. The task of expressing negative moral judgements about the content of the objector's beliefs does not contribute to that urgent task and is therefore futile for the real task at hand. We only need to look at the consequences of the purported acts of the objector and not to the quality of his beliefs.

One may object, as Nehushtan does, to this second argument. He says that expressing a view about the content of the objector's belief may make a practical difference to the outcome. He gives the example of a prospective non-white employee who seeks employment from an employer who, for religious reasons, holds that white people should not mix with non-whites and therefore refuses to employ the prospective non-white employee. Nehushtan assumes in this scenario that there is no serious problem of racism in the employment market and that the prospective employee immediately finds employment with another employer. Nehushtan argues that given that the employee will not have suffered any meaningful harm, except perhaps a slight offence having found alternative employment, it would not be possible to condemn the employer's behaviour unless the state takes

\footnotetext{
${ }^{46}$ Timothy Macklem, Independence of Mind (Oxford University Press 2008) 133-134.
} 
into account the religiously motivated racist quality of his beliefs and denies the exemption on that basis. ${ }^{47}$

Nehushtan's example is not a good one against state neutrality for two reasons. First, if there are no good reasons to prohibit a religiously motivated act then that act should not be prohibited. It is not, as Nehushtan argues, that we decide that certain acts are not acceptable and then seek reasons to prohibit them (in this case judging the quality of the conviction that gave rise to the non-employment). Nehushtan's argument is essentially one which allows prejudice against religion and then looks for post-facto justifications for that prejudice. Secondly, there is in fact a strong reason for prohibiting the act of the employer without having to judge the quality of his beliefs: his refusal to employ the nonwhite prospective employee for the reason of his race is seriously humiliating and hence harmful. Not only does the humiliation provide reasons for offence and may occasion psychological harm, it also sends the signal that the non-white employee is a lesser member of society because a lesser human being. In a society where such acts are allowed, victims of such humiliation are likely to suffer loss of self-respect and self-worth, in short their wellbeing is seriously harmed. ${ }^{48}$ This alone is a sufficient reason for not allowing such acts; it is unnecessary to have to judge the content of the employer's beliefs.

\section{Does claiming a legal right to exemption deserve a negative moral judgement?}

The previous section explained that sound moral analysis seems to lead to the conclusion that the state should be neutral about conscientious objectors' beliefs. However, before affirming that conclusion a strong counter-argument needs to be addressed. This counter-argument says that it may well be that morally sound legal doctrines prohibit judges from expressing a negative moral judgement about the content of objectors' beliefs. However, that does not preclude another kind of negative judgement about the objectors. In particular, conscientious objectors may be viewed as undermining the authority of the law by objecting to complying with their legal obligations and as obstructing whatever public good the law they object to can be interpreted to be pursuing. For example, on the assumption that the obligation to file tax returns online serves the purpose of an efficient tax system, Mr Bible Believer and Mr Climate Change should be viewed negatively for trying to obstruct the pursuit of this purpose and generally for trying to escape the obligations the law has imposed on them. While a judge may nevertheless grant an exemption (for whatever principled or prudential reason), the judge should necessarily be viewed as condemning the law-undermining attitude of the objectors. After all, one of the essential roles of judges is to enforce the law so they necessarily ought to condemn those who seek to escape their legal obligations (whether or not for reasons of conscience).

This counter-argument, while very intuitive, is misplaced primarily because it is addressed to the wrong target. Conscientious objectors, by contrast to non-conscientious law breakers and some instances of civil disobedience, do not seek to escape their legal obligations; they claim instead that they have a legal right not to comply with particular legal obligations. ${ }^{49} \mathrm{Mr}$ Bible Believer and $\mathrm{Mr}$ Climate Change, for example, claim exemption from the online tax filing requirement on the basis of a particular exemption provided in a particular piece of legislation or regulation. ${ }^{50}$ They are asserting that the law has provided that they be exempt and are simply asserting their legal right. This is the

\footnotetext{
${ }^{47}$ Nehushtan, Intolerant Religion (n 9) 146-147.

${ }^{48}$ This is an argument borrowed from Jeremy Waldron, The Harm in Hate Speech (Harvard University Press 2014) ch 5 . Waldron refers to dignitary harm while the present argument refers to humiliation, mainly because of the sometimes open-textured meaning of dignity in the literature.

${ }^{49}$ This argument was borrowed from Ronald Dworkin, Taking Rights Seriously (Harvard University Press 1978) ch 8.

${ }^{50}$ See $n 1$.
} 
same type of claim asserted by other conscientious objectors considered above. In Hobby Lobby, the company claimed a legal right under RFRA not to be coerced to provide mandatory contraceptive cover. In Amselem, the property owners were claiming a right under the provisions of freedom of religion under the Quebec and the Canadian Charters not to be compelled to comply with bye-laws that would prevent them from building their own succahs. In Eweida, the applicants invoked article 9 ECHR protecting religious freedom not to be compelled to comply with their employers' ban of their necklaces with crucifixes. Rather than escaping their legal obligations, these objectors were merely claiming that the law, properly construed, did not impose on them the obligations they objected to. In these cases the courts accepted the objectors' assertion of the existence of a legal right to exemption. Objectors deserve no moral condemnation for asserting their legal rights.

Of course, asserting the existence of a particular legal right is entirely different from having one. No doubts certain individuals will unscrupulously conjure creative legal claims to mask their law-breaking efforts. Take the US case of Quaintance to see that this is a serious issue. ${ }^{51}$ In that case, a group of related individuals who were the founding members of the Church of Cognizance were charged with being in possession of $50 \mathrm{~kg}$ of marijuana. The alleged core belief of the members of this church is that 'marijuana is a sacrament and deity and that the consumption of marijuana is a means of worship'. ${ }^{2}$ They maintained that the criminal prohibition of narcotics substantially burdened their religious beliefs and was in violation of the RFRA. The trial judge was faced with the challenge to determine whether their claim was sincere or whether 'the Quaintances were acting for the sake of convenience, i.e. because they believed the church would cloak [them] with the protection of the law'. ${ }^{53}$ Having determined that they were drug traffickers who made use of and sold other drugs, including cocaine, the judge found for the latter option. But note that the issue in this case was not that a legal right to be exempt from the prohibition of narcotics does not exist. Other US cases, in relation to Rastafarians for example, have held that it does exist. ${ }^{54}$ The issue was whether the claimants qualified for that right; because the enjoyment of the right depended on a sincere conscientious objection the insincere claimants were held not to qualify.

Conscientious objectors ought not to be judged negatively for claiming the existence of a legal right to exemption from particular legal obligations. No doubt individuals who insincerely pretend to hold a conscientious objection should be judged negatively for their insincerity. But, by definition, these insincere claimants are not actually conscientious objectors. Also, it is not disputed that conscientious objectors are seeking to escape particular legal obligations, e.g. filing tax returns online. However, that does not mean that they are undermining the authority of law. As long as they make a genuine legal claim that another law exempts them from complying with a particular legal obligation they are respecting legal authority because they are employing legal means.

Note that conscientious objectors do not argue that it is their conscience that relieves them from a particular legal duty. While it is their conscience that leads them to object to a particular legal duty, they claim that it is the law that should relieve them from that legal duty. In sum, they ask courts to resolve a conflict between two legal norms, one imposing a particular legal obligation they object to, and the other granting them a legal right to exemption. Conscientious objectors deserve no moral condemnation for that request because that is a routine affair of the law. Journalists, for example, will claim that particular laws protecting private life conflict with their legal right to publish information which is in the public interest (e.g. regarding extra-marital affairs of a politician). No one should suggest that such claimants, if they make their case in good faith and conscientiously, deserve condemnation for seeking to escape the laws protecting private life.

\footnotetext{
${ }^{51}$ US v Quaintance (2010) 608 F 3d 717 (Court of Appeals, 10th Circuit). The first instance judgment is US v Quaintance (2006) 471 F Supp 2d 1153 (Dist Court).

52 Quaintance (2006) (n 51) 1155.

53 ibid 1174.

${ }^{54}$ United States v Valrey 2000 WL 692647 (Washington District Court).
} 
In sum, the principle of toleration cannot bite simply based on the fact that conscientious objectors assert their legal rights because such an assertion should not invite negative moral judgement. We may of course wonder why the law should grant them such a right to exemption in the first place. For the reasons illustrated in this part, we ought not to look at the principle of toleration. We will do better to look elsewhere. The next part tentatively sets out the moral basis of such a legal right to exemption.

\section{Conscientious Exemptions: From Neutrality to Respect}

The conclusion reached in the last part that the principle of toleration cannot describe or guide the practice of conscientious exemptions might lead to a serious worry. The worry is that there is no principled reason for granting conscientious exemptions. In fact, if Nehushtan had been right then we would have had a prima facie reason to entertain the claims of Mr Bible Believer and Mr Climate Change: they have a right to be tolerated. In fact, on the (contested) assumption that toleration is a political virtue ${ }^{55}$ we may have had a normative reason to exempt the objectors: we want the state to act virtuously and we thereby grant a right to exemption. However, if exempting objectors is not linked to the virtue of toleration, we no longer have a principled reason to grant exemptions to the two claimants. Sure, there might be pragmatic or supererogatory reasons. We might, for example, think that it makes no difference to an efficient tax system whether businesses submit their tax returns online or on paper so exemptions may be granted from what appears to be a very ad hoc rule of requiring online tax returns. Alternatively, we might think that while the general rule has serious merits (e.g. the online system can help HMRC spend fewer resources when collecting taxes or help it combat tax evasion), the state ought not to be too harsh on those few who object to the rule. An exemption may thereby be granted as an act of kindness.

The pragmatic and supererogatory responses do not however make sense of the right-based language of the practice of conscientious exemptions. As articulated above, under RFRA, the ICCPR, the ECHR and other legal instruments, individuals claim a non-absolute right to conscientious exemption and the state is under an obligation to comply with such a claim unless doing so would undermine a compelling government interest (in the case of RFRA) or important public interests or the right of others (in the case of the ICCPR or the ECHR). It may well be that these documents are misguided and do not reflect any underlying moral right to exemption. There is high judicial precedent for this view. The Free Exercise Clause of the First Amendment of the US Constitution ('Congress shall make no law respecting an establishment of religion, or prohibiting the free exercise thereof') used to be interpreted as granting a general non-absolute right to conscientious exemption for religious objectors. ${ }^{56}$ However, in Smith, the USSC decided that this approach was not principled. Justice Scalia, speaking for the majority said

The government's ability to enforce generally applicable prohibitions of socially harmful conduct, like its ability to carry out other aspects of public policy, "cannot depend on measuring the effects of a governmental action on a religious objector's spiritual development." (...) To make an individual's obligation to obey such a law contingent upon the law's coincidence with his religious beliefs, except where the State's interest is "compelling" -permitting him, by virtue of his beliefs, "to become a law unto himself," (...) contradicts both constitutional tradition and common sense. ${ }^{57}$

\footnotetext{
55 See $n$ Error! Bookmark not defined. above.

56 This interpretation lasted for about 30 years starting with Sherbert $v$ Verner (526) 374 US 398 (Supreme

Court) and Wisconsin v Yoder (1971) 406 US 205 (Supreme Court).

${ }^{57}$ Smith (n 33) 885.
} 
Others have joined in to criticise the existence of a right to conscientious exemption. Some argue that exemptions should not be granted as they involve subsidising what are essentially expensive tastes: individuals should bear the responsibility for the consequences of the beliefs they endorse even though those consequences may be very costly. ${ }^{58}$ Others say that if there is a sufficiently strong reason to grant an exemption that reason should ordinarily be strong enough to motivate changing the rule so that it no longer encroaches on the objectors. A 'rule and exemption' approach betrays the egalitarian commitment that members of a political society should all be ruled by the same standards. ${ }^{59}$ A more recent argument says that conscientious exemptions undermine the sovereignty of the liberal democratic state by requiring it to bow down to the assertion of a citizen's commitment to other sources of moral sovereignty, including religious sovereignty. ${ }^{60}$

All of these arguments give serious reasons to believe that the rights-based language of the practice of conscientious exemptions is not only unprincipled, but it is also misguided. A way to investigate whether that conclusion is warranted is either to face head-on these counter-arguments to the rightsbased language and see whether they withstand scrutiny or, alternatively, to point to another principle, other than toleration, which may justify the use of a right-based language for that practice. For reasons of succinctness, this paper takes the latter approach. This means that those counterarguments, together with the doubts they give rise to, may still survive. However, if the practice is based on an attractive principle, that principle may partially override the worries created by the identified counter-arguments. The argument to be advanced is that there is not only one principle grounding the rights-based practice of conscientious exemptions. There is a cluster of mutually reinforcing moral principles which justify that practice.

\section{A. Respecting values}

To see that the practice of conscientious exemptions is not without moral foundation we need to start by borrowing from the argument from pluralism made above. It was argued that the state should not judge the content of the beliefs of conscientious objectors because, among other things, that would run counter to the individual responsibility to determine what lifestyle is worthwhile. It was said that various incompatible lifestyles each exhibit something worthwhile, even while exhibiting several drawbacks, and it is up to each individual to weight for himself what is more worthwhile for him. Importantly, given that it is the individual that will benefit or suffer the consequences of the lifestyle, the choice of which lifestyle to follow is his and not the state's.

If this is accepted it may partially ground a claimed right to conscientious exemption. In fact when the state imposes a general rule, that rule may create a barrier to an individual's chosen lifestyle (e.g. the prohibition of drug possession may create a barrier to living according to the Rastafarian ceremonial use of cannabis). That may of course be another of the drawbacks of being committed to that lifestyle and the individual may need to reconsider whether that lifestyle is really worth it with the burden which the state has imposed. However, remember that the argument from pluralism is essentially an argument for state neutrality. In imposing a particular rule which creates a barrier to the pursuit of a particular lifestyle, the state may be portrayed as violating its duty of neutrality: the state makes certain lifestyles less accessible and thereby incentivises individuals to choose other lifestyles (i.e. the more accessible ones). If the state is to remain neutral among competing lifestyles it should therefore grant an exemption to alleviate the barrier it has created. Of course, the imposition of the particular

\footnotetext{
${ }^{58}$ Brian Barry, Culture and Equality: An Egalitarian Critique of Multiculturalism (Harvard University Press 2002) 34-36. See also Peter Jones, 'Bearing the Consequences of Belief' (1994) 2 Journal of Political Philosophy 24.

${ }^{59}$ Barry (n 58) generally chapter 2.

60 Jean L Cohen, 'Freedom of Religion, Inc.: Whose Sovereignty?' (2015) 44 Netherlands Journal of Legal Philosophy 169.
} 
rule may be justified by reference to vital public interests or to the rights of others (e.g. combating drug-related criminality). So the granting of the exemption will depend on whether it would seriously undermine those interests and rights. This is however a reason to make the right to exemption nonabsolute rather than rejecting the right altogether.

The argument above is essentially one that derives a non-absolute right to exemption from the state's duty of neutrality. It is an argument calling for the state to respect and promote pluralism. But notice that there are other values at play here that reinforce this argument. The most obvious is perhaps the insistence that personal autonomy should be respected by the state. The idea of personal autonomy 'is that people should make their own lives. The autonomous person is a (part) author of his own life. The ideal of personal autonomy is the vision of people controlling, to some degree, their own destiny, fashioning it through successive decisions throughout their lives'. ${ }^{61}$ It is possible to argue that committing oneself to a particular lifestyle (e.g. one committed to a particular religion) is an expression of personal autonomy. The person that is committed to a particular religion will make a variety of choices which will have a myriad of implications for his life. A portion of those implications would have been different had he committed himself to another religion or to non-religion. By being allowed to be committed to any religion or non-religion the individual is thereby being allowed to lead a more autonomous life and to shape the course of his life. The state that values and respects personal autonomy will thereby allow the freedom for individuals to pursue whichever lifestyle they identify with. Of course, as discussed multiple times, the state cannot permit all expressions of every lifestyle. Some will collude with fundamental public interests and/or the rights of others. However, the state's respect for personal autonomy leads to respecting various manifestations of different lifestyles, although not of all.

Respect for personal autonomy does not directly lead to justifying the assertion of a right to be exempt from various legal duties. However, respect for autonomy leads to reinforcing the case for that right: if the state grants exemptions (perhaps on the basis of state neutrality sketched above) that promotes personal autonomy and that is virtuous. In fact, as stated, an exemption from a legal duty incompatible with a lifestyle diminishes the costs of accessing or continuing to identify with a particular lifestyle; it increases options for individuals. Personal autonomy is about, among other things, access to an adequate range of options. ${ }^{62}$ By granting an exemption the state increases the range of lifestyles which an individual may identify with and live according to. It thereby promotes personal autonomy.

Respect for personal autonomy reinforces the case for granting conscientious exemptions. However, respecting autonomy also usually involves, at least in the context of conscientious objection, respect for liberty of conscience. We may understand conscience as a person's faculty 'for searching for life's ethical basis and its ultimate meaning'. ${ }^{63}$ Consequently, we may understand liberty of conscience as the liberty to live one's life according to the normative imperatives imposed by conscience. These normative imperatives may originate from religious directives or from non-religious ones.

Commitment to a particular lifestyle, whether religious or not, will normally include a judgement that the lifestyle is compatible and/or required by one's conscientious convictions. Otherwise the individual would find himself living in a pathological bipolar situation whereby he considers a lifestyle valuable but completely at odds with his convictions about what is right or wrong. No doubt such pathological cases exist. A professional killer may be committed to his lifestyle because of its luxurious rewards while fully appreciating its moral wrongness. However, in non-pathological cases, individuals subscribe to a particular lifestyle, among other things, because they believe it to be right or morally

\footnotetext{
61 Joseph Raz, The Morality of Freedom (Oxford University Press 1988) 369.

62 ibid 372. Raz says that 'The conditions of autonomy are complex and consist of three distinct components: appropriate mental abilities, an adequate range of options, and independence.'

${ }^{63}$ Martha C Nussbaum, 'Liberty of Conscience: The Attack on Equal Respect' (2007) 8 Journal of Human Development 337, 342.
} 
required. This is usually the case for religious lifestyles. Individuals commit to living according to the edicts of a particular religion because they believe that living that way is required by God, the main source of their moral imperatives. It is their belief in a deity that leads them to commit to a particular lifestyle. In order words, it is liberty of conscience which influences the way they exercise their right to personal autonomy. It follows that when the state respects personal autonomy by granting an exemption it normally also respects freedom of conscience.

When the state refuses to grant an exemption this may not only encroach on personal autonomy or freedom of conscience; it may occasion harm to the objector, i.e. undermine her wellbeing. Remember that when an exemption is denied the objector may be coerced to perform an act which she believes to be wrong. Using the usual example, if Mr Bible Believer's and Mr Climate Change's claims for exemptions are denied they will be coerced to file their tax return online. But doing such act goes against their conscience and that might undermine their well-being. In fact when an individual makes a claim of conscience she is normally so committed to her beliefs that acting against them 'would result in a loss of personal and moral integrity with consequences, such as profound guilt and remorse, which would have an adverse effect on the person's self-conception and self-respect'. This, in turn, would affect the person's well-being. ${ }^{64}$ Of course the individual may refuse to yield to legal coercion and pay the consequences, e.g. close down their business because they cannot file their tax returns on non-electronic means. However, succumbing to legal punishment rather than acting against one's conscience also undermines one's well-being. It follows that when the state grants a conscientious exemption it is usually also paying respect to an aspect of the objector's wellbeing.

\section{Conclusion: Treating Religious and Non-Religious Conscientious Objectors Alike}

If the arguments of the preceding part are correct, they entail that a non-absolute right to conscientious exemption is justified by reference to a cluster of values, including respect for state neutrality, personal autonomy, freedom of conscience and concern for well-being. No doubt other arguments could be made to show that other values are involved. ${ }^{65}$ However, these suffice to temporarily ground the practice of granting conscientious exemptions in recognisable moral values. Remember, however, that the practice cannot be fully morally justified until the objections to it which were illustrated above ${ }^{66}$ are overcome. That task is left for another day. The discussion until now should bring some confidence that the rights-based discourse of conscientious exemptions is not senseless. Furthermore, it also provides another reason not to heed to Nehushtan's insistence that the principle of toleration grounds the practice of conscientious exemptions. If, as argued, we can make reference to an alternative cluster of principles we need not make reference to the principle of toleration.

What can the cluster of moral principles identified tell us about how to adjudicate conscientious exemption claims? Apart from telling us that there are good reasons to think that the claims are correctly framed as a matter of right, the cluster also militates against various theorists' insistence that religious claimants should be, all things being equal, more or less likely to lose their claims that nonreligious claimants depending on whether religion is judged to be inherently worthy or blameworthy. In fact the cluster of principles seems to be insensitive to the religious or non-religious nature of the beliefs of the conscientious objectors. The state's duty of neutrality is specifically against unequal treatment depending on the nature of the beliefs. Also, respect for autonomy, conscience and well-

\footnotetext{
${ }^{64}$ John Adenitire, 'SAS v France: Fidelity to Law and Conscience' [2015] European Human Rights Law Review $78,82$.

${ }^{65} \mathrm{~A}$ further argument based on the state's ambition not to govern through coercion but mainly through the idea of fidelity to law was made in Adenitire ( $n 64)$.

${ }^{66}$ See text from $\mathrm{n} 56$ to $\mathrm{n} 60$.
} 
being are insensitive to the particular content of the beliefs of the objectors. The only criterion considered is that exemptions should not be granted if that would result in undermining fundamental public interests or the rights of others. That criterion is neutral to the religious or non-religious nature of the belief involved.

So what is the implication of the discussion for Mr Bible Believer and Mr Climate Change? The legislative right to be exempt from the duty to file their tax returns online reflects an underlying and more general moral right to conscientious exemption. It is a right that both should equally have the ability to claim and to enjoy. Furthermore, we should view the grant of the legislative right as a determination by the legislature that the exemption will not undermine fundamental public interests or the rights of others. That determination is of course open to challenge but that would necessitate an in depth analysis of the purposes of the requirement of online tax filing and how that requirement serves the public interest. That analysis is left for another day. 